\title{
Cotransduction of Morganocinogenic Plasmid 174 and R Factor R772
}

\author{
By J. N. COETZEE, KATHRYN KRIZSANOVICH-WILLIAMS \\ AND J. A. WILLIAMS \\ Department of Microbiology, University of Pretoria, South Africa, and \\ Microbial Genetics Unit of the South African Medical Research Council
}

(Received 24 November 1976)

\begin{abstract}
SUMMAR Y
Attempts were made to obtain recombinants between the morganocinogenic factor Mor 74 and R plasmid R772 by transductional techniques. Transduction frequencies of the kanamycin resistance marker of $\mathbf{R} 772$ to Proteus mirabilis PM5006 or Providence P29 carrying MorI74 by phages 5006M and PL25, respectively, were I000-fold higher than to the corresponding Mor I $74^{-}$strains. The frequency of phage PI-mediated transduction of the same marker to Escherichia coli $\mathrm{J} 62$ was high and was not affected by the presence of MorI74 in the recipient. Transduction of the kanamycin resistance marker to PM5006 yielded heterogenotelike transductants. Transduction of the same marker to PM5006 with MorI74 as resident resulted in transductants which not only yielded low frequency kanamycin resistance transducing particles on induction but could transfer MorI 74 and the transduced marker independently by conjugation. It was suggested that Mor 74 exerted some function in establishing a transductionally shortened R factor. Mor 174 also possibly played a role in the separation of the phage component of the transducing particle from the $\mathrm{R}$ factor portion. The severed phage genes could then integrate in tandem to a cryptic prophage to render transductants inducible. A phage $5006 \mathrm{M}$ lysate of PM5006(MorI 74R 772) produced a cotransductant. This transductant could not, possibly due to more extensive transductional shortening, transfer markers by conjugation. Induction yielded some particles which could cotransduce the markers to PM5006(P-lac). With assistance of the latter conjugative plasmid, markers of MorI 74 and R772 were transferred as a unit by conjugation to strain J62. Phage PI reared on the latter transconjugant cotransduced the genes for MorI74 activity and kanamycin resistance. Morganocin production by the recombinant equalled that of Mori 74 .
\end{abstract}

\section{INTRODUCTION}

Proteus morganii 174 carries a bacteriocinogenic plasmid (Mor I74) which codes for the synthesis of morganocin 174 , but although morganocin synthesis can be induced, the yield of morganocin is low (Williams, 1977). The plasmid is non self-transmissible but may be mobilized by $\mathrm{R}$ factor $\mathrm{R} 772$ (Williams, 1977 ; and see below). In an attempt to obtain higher yields of morganocin by altering the structure of the morganocinogenic plasmid, we tried to isolate a recombinant between the latter and $R_{772}$ by using transduction techniques. To select bacteriocinogenic transductants of a sensitive strain, use may be made of the fact that a bacteriocinogenic cell accumulates immunity substance. However, lack of an organism sensitive to both morganocin and a transducing phage precluded direct selection for Mor $74^{+}$ transductants. Consequently $\mathrm{R}_{772}$ was transduced into Mor I74-containing organisms in the hope that, amongst other events, possible transductional shortening (Shipley \& Olsen, 
Table I. Bacteria, bacteriophages and plasmids

\begin{tabular}{|c|c|c|c|}
\hline Bacteria & \multicolumn{2}{|c|}{ Properties* } & Reference \\
\hline $\begin{array}{l}\text { Proteus mirabilis } \\
\text { PM5006 }\end{array}$ & $\begin{array}{l}\text { Host for phage } 5006 \mathrm{M} \text {. } \\
\text { phage } 5006 \mathrm{M} \text {. Not susc } \\
\text { I74. Resistant to } \mathrm{T} \text { and }\end{array}$ & $\begin{array}{l}\text { ryptically lysogenic for } \\
\text { ptible to morganocin } \\
\text { PMX }\end{array}$ & $\begin{array}{l}\text { Coetzee \& Smit (1970) } \\
\text { Krizsanovich (1973) } \\
\text { Coetzee (unpublished) }\end{array}$ \\
\hline PM5006nal-r & Spontaneous mutant res & tant to $100 \mu \mathrm{g} \mathrm{Nal} \mathrm{ml}{ }^{-1}$ & Coetzee $(1974 b)$ \\
\hline $\begin{array}{l}\text { Proteus morganii } \\
\quad P . \text { morganii } 174\end{array}$ & $\begin{array}{l}\text { Has morganocinogenic } \\
\text { resident. Resistant to } A \\
\text { approximately } 3 \times 10^{6}\end{array}$ & $\begin{array}{l}\operatorname{asmid} 174(\text { Mor I } 74) \text { as } \\
\text { MorI } 74 \text { circular DNA } \\
\text { lton }\end{array}$ & $\begin{array}{l}\text { Williams (I977) } \\
\text { Williams, Krizsanovich- } \\
\text { Williams \& Harley } \\
\text { (unpublished) }\end{array}$ \\
\hline P. morganii 163 str-r & $\begin{array}{l}\text { Wild-type strain, sensitiv } \\
\text { Spontaneous mutant re } \\
\text { Morganocin } 174 \text { indica }\end{array}$ & $\begin{array}{l}\text { to morganocin } 174 \text {. } \\
\text { stant to I } \mathrm{mg} \mathrm{S} \mathrm{ml}^{-1} \text {. } \\
\text { r }\end{array}$ & Williams (1977) \\
\hline \multicolumn{4}{|l|}{ Providence } \\
\hline P29 & $\begin{array}{l}\text { Providence strain NCTC9 } \\
\text { for general transducing } \\
\text { to A. Not susceptible t }\end{array}$ & $\begin{array}{l}\text { I I. Biogroup I. Recipient } \\
\text { hage PL25. Resistant } \\
\text { morganocin I74 }\end{array}$ & $\begin{array}{l}\text { Coetzee, Smit \& Prozesky } \\
\text { (1966) }\end{array}$ \\
\hline P29nal-r & Spontaneous mutant res & tant to $100 \mu \mathrm{g} \mathrm{Nal} \mathrm{ml}^{-1}$ & Coetzee $(1974 b)$ \\
\hline $\begin{array}{l}\text { Escherichia coli } \\
\mathrm{J} 62\end{array}$ & $\begin{array}{l}\mathrm{F}^{-}, \text {lac, pro, his, trp mut } \\
\text { susceptible to morgano }\end{array}$ & $\begin{array}{l}\text { nt of } E \text {. coli KI2. Not } \\
\text { n I74 }\end{array}$ & Clowes \& Hayes (1968) \\
\hline$J 62-I$ & Spontaneous mutant res & tant to $100 \mu \mathrm{g} \mathrm{Nal} \mathrm{ml} \mathrm{m}^{-1}$ & $\begin{array}{l}\text { Coetzee, Datta \& } \\
\text { Hedges (1972) }\end{array}$ \\
\hline Bacteriophages & Prop & rties & Reference \\
\hline $5006 \mathrm{M}$ & $\begin{array}{l}\text { Cryptic prophage of PM5 } \\
\text { infection of PM5006. Ge } \\
\text { PM5006. Linear DNA a }\end{array}$ & $\begin{array}{l}\text { o6. Produced by lytic } \\
\text { eralized transducing for } \\
\text { prox. } 23 \times 10^{6} \text { dalton }\end{array}$ & $\begin{array}{l}\text { Krizsanovich (I973) } \\
\text { Coetzee (I974 b) } \\
\text { Coetzee, Lecatsas \& } \\
\text { Coetzee (unpublished) }\end{array}$ \\
\hline PL25 & Generalized transducing & or P29 & Coetzee et al. (1966) \\
\hline PI & $\begin{array}{l}\text { Generalized transducing } \\
\text { Linear DNA } 60 \times 10^{6} \mathrm{~d}\end{array}$ & $\begin{array}{l}\text { or } E . \text { coli KI2 strains. } \\
\text { ton }\end{array}$ & $\begin{array}{l}\text { Ikeda \& Tomizawa } \\
(1965,1968)\end{array}$ \\
\hline Plasmids and hosts & Properties* & Incompatibility group & Reference \\
\hline 362-I(R772) & $\begin{array}{l}\text { K. Circular DNA } \\
\text { approx. } 27 \times 10^{6} \\
\text { dalton }\end{array}$ & Undetermined & $\begin{array}{l}\text { Hedges (I975) } \\
\text { Williams \& Krizsanovich- } \\
\text { Williams (unpublished) }\end{array}$ \\
\hline J62-I $\left(\mathbf{R}_{447} b\right)$ & $\mathrm{A}, \mathrm{K}$ & $\mathrm{N}$ & Hedges et al. (1973) \\
\hline $\begin{array}{l}\text { PM5006(R772) } \\
\text { PM5006(R447b) }\end{array}$ & $\begin{array}{l}\text { as above } \\
\text { as above }\end{array}$ & $\begin{array}{l}\text { as above } \\
\text { as above }\end{array}$ & \\
\hline PM5006(R392) & $\mathbf{K}$ & ?J & Coetzee et al. (1972) \\
\hline PM5006(R397) & $\mathbf{K}$ & $? \mathrm{~J}$ & Hedges et al. (I975) \\
\hline PM5006(R753) & $\mathrm{A}, \mathrm{C}, \mathrm{S}, \mathrm{Su}$ & V & Hedges (I975) \\
\hline PM5006(R755) & $\mathrm{A}, \mathrm{C}, \mathrm{S}, \mathrm{Su}$ & V & Hedges (1975) \\
\hline PM5006(R905) & $\mathrm{C}, \mathrm{S}, \mathrm{Su}$ & V & Hedges (I975) \\
\hline PM5006(RS-a) & $\mathrm{C}, \mathbf{K}, \mathbf{S}, \mathbf{S u}$ & W & Hedges \& Datta (197I) \\
\hline PM5006(R192drd7) & $\mathrm{C}, \mathrm{S}, \mathrm{Su}, \mathrm{T}$ & FII & Meynell \& Datta (I966) \\
\hline PM5006(P-lac) & $\mathrm{Su}$, lactose utilization & A-C & Hedges (I975) \\
\hline P. morganii I $74(\mathrm{RI} d r d \mathrm{I} 9)$ & $\mathrm{A}, \mathrm{C}, \mathrm{K}, \mathrm{S}, \mathrm{Su}$ & FII & $\begin{array}{l}\text { Meynell \& Datta (1967) } \\
\text { Coetzee (unpublished) }\end{array}$ \\
\hline P. morganii $\mathrm{I} 74(\mathrm{R} 772)$ & as above & as above & Coetzee (unpublished) \\
\hline P. morganii $174\left(\mathrm{R}_{447} \mathrm{~b}\right)$ & as above & as above & Coetzee (unpublished) \\
\hline P. morganii 174(P-lac $)$ & as above & as above & Coetzee (unpublished) \\
\hline
\end{tabular}

* Symbols signify resistance to: A, ampicillin; C, chloramphenicol; K, kanamycin; Nal, nalidixic acid; PMX, polymixin B sulphate; $S$, streptomycin; Su, sulphonamide; T, tetracycline. 
I975) would result in a recombinant. When $\mathbf{R} 772$ was similarly transduced into the corresponding MorI $74^{-}$organisms the transduction frequency was strikingly lower. This paper describes investigations into the nature of the interaction between R772 and MorI74.

\section{METHODS}

Bacteria, plasmids and phages. These are listed in Table I.

Media and antibiotics. Nutrient broth was Oxoid no. 2, code CM67; nutrient agar was the same broth solidified with $\mathrm{I} \cdot 2 \%$ (w/v) Difco agar. MacConkey agar was from Difco. The incubation temperature was $37^{\circ} \mathrm{C}$. Ampicillin, chloramphenicol, tetracycline, nalidixic acid, streptomycin, kanamycin and polymixin B were used at $50 \mu \mathrm{g} \mathrm{ml}^{-1}$.

Production of phage lysates and general phage techniques. The methods described by Adams (1956) and Coetzee (1974b) were used. Lysates of phages 5006M.PM5006(R772), 5006M.PM5006(MorI74R772), PL25.P29(R772) and PL25.P29(MorI74R772) had titres of $7 \times 10^{10}$ to $9 \times 10^{10}$ plaque-forming units (p.f.u.) $\mathrm{ml}^{-1}$. Phage lysates were sterile.

Transduction. The Millipore membrane filter technique (Coetzee, 1974b) was used. A superior line indicates that the marker was transduced.

Phage induction. Ultraviolet (u.v.) light induction was according to Coetzee (1974b). Transductants PM5006(MorI74 $\overline{\mathrm{R}_{772}}$ ) and P29(MorI74 $\overline{\mathrm{R} 772}$ ) yielded plaque-forming titres of $\mathrm{I} \times 10^{9}$ and $5 \times 10^{8}$ p.f.u. $\mathrm{ml}^{-1}$ respectively.

Concentration of phage lysates. The method described for phage P22 by Yamamoto \& Alberts (1970) was used.

Detection of morganocinogeny and assay of morganocin. This was done as described by Williams (1977).

Conjugal transfer of plasmids. This was done according to Coetzee et al. (1973).

Selection of segregants. The methods of Coetzee (I975) and Williams (1977) were used.

\section{RESULTS}

\section{Mobilization of Mor 74}

Mor 74 was non self-transmissible within the limits of the methods used but it transferred to various hosts in the presence of $R$ plasmid $R 772$ (but see Hedges, 1975) and all of a small number of other self-transmissible plasmids subsequently tested (Table 2). Transconjugants of some of the crosses which had received markers of both the conjugative plasmid and the bacteriocinogenic factor were designated PM5006(MorI74R772), P29nal-r(Mor 174R772), J62-I(Mori74R772) and PM5006(Morr74R447b).

Properties of Mori 74 transconjugants. Markers of the two plasmids carried by these hosts were lost spontaneously and independently at low frequencies (not shown) and those strains which had lost the kanamycin resistance marker of $\mathbf{R} 77^{2}$ were designated PM5006(MorI 74R772) $\mathrm{K}^{\mathrm{s}}$ etc. to indicate that loss of expression of the resistance marker did not necessarily imply defective segregation of the plasmid. Subsequently spontaneous onestep kanamycin- and ampicillin-sensitive derivatives of PM5006(MorI74R447b) were also obtained. Transfer of MorI74 by these antibiotic-sensitive derivatives of Mor 74 transconjugants was not detected (transfer frequency $<\mathrm{I} \times \mathrm{IO}^{-5}$ per donor cell). Kanamycinsensitive derivatives of transconjugants designated PM5006(R772) $\mathrm{K}^{\mathrm{s}}$ etc. which had only received $R_{772}$ (Table 2) were also obtained. None of the antibiotic-sensitive derivatives mentioned above exhibited surface exclusion towards the entry of homologous plasmids (Table 3.) 


\section{Table 2. Mobilization of MorI 74}

Stationary-phase recipient cultures were mixed with exponentially growing donor cultures at a ratio of $4: 1, v / v$. Mixtures were incubated for $\mathrm{I} h$ before samples were plated on selective media and incubated for $48 \mathrm{~h}$. For details, see Methods.

\begin{tabular}{|c|c|c|c|c|c|}
\hline Donor & Recipient & $\begin{array}{l}\text { Donor } \\
\text { counter- } \\
\text { selection }\end{array}$ & $\begin{array}{l}\text { Selected } \\
\text { marker }\end{array}$ & $\begin{array}{c}\text { Selected } \\
\text { marker } \\
\text { transfer* }\end{array}$ & $\begin{array}{c}\text { Cotransfer of } \\
\text { morgano- } \\
\text { cinogeny }\end{array}$ \\
\hline P. morganii I74 & PM5006 & $\mathbf{T}$ & Mori $74 \ddagger$ & $<3.3 \times 10^{-5}$ & 一 \\
\hline P. morganii $174\left(\mathrm{R}_{772}\right)$ & PM5006 & $\mathbf{T}$ & $\mathbf{K}$ & $1 \times 10^{-6}$ & $9 / 20$ \\
\hline P. morganii $174\left(\mathrm{R}_{772}\right)$ & P29nal-r & $\mathrm{Nal}$ & $\mathbf{K}$ & $\mathrm{I} \times 1 \mathrm{IO}^{-5}$ & $4 / 20$ \\
\hline P. morganii $174\left(\mathrm{R}_{772}\right)$ & J62-I & $\mathrm{Nal}$ & $\mathbf{K}$ & $5 \times 10^{-5}$ & $6 / 20$ \\
\hline P. morganii $\mathrm{I} 74(\mathrm{R} 447 b)$ & PM5006 & $\mathrm{T}$ & $\mathbf{K}$ & $I \times 10^{-6}$ & $5 / 10$ \\
\hline P. morganii $\mathrm{I} 74(\mathrm{R} \mathrm{I} d r d \mathrm{I} 9)$ & PM5006 & $\mathrm{T}$ & $\mathbf{K}$ & $\mathrm{I} \times 1 \mathrm{IO}^{-\mathbf{3}}$ & $8 / 10$ \\
\hline P. morganii $174(\mathrm{P}-l a c)$ & PM5006 & $\mathrm{T}$ & lac & $\mathrm{I} \times 1 \mathrm{IO}^{-3}$ & $8 / 20$ \\
\hline
\end{tabular}

* Frequency per donor cell.

$\uparrow$ Denominator indicates the number of transconjugants tested.

$\$$ No selection for Morr 74 was possible.

\section{Table 3. Transfer of $\mathrm{R} 772$ to kanamycin-sensitive derivatives of $\mathrm{R}_{772}$ transconjugants}

Conjugation experiments were done as described in Table 2. Donors were counterselected with polymixin B sulphate and selection was for kanamycin resistance. Morganocinogeny was tested by replication of transconjugant clones to streptomycin agar seeded with a lawn of morganocin indicator bacteria.

\begin{tabular}{|c|c|c|c|}
\hline Donor & Recipient & $\begin{array}{l}\text { Selected marker } \\
\text { transfer* }\end{array}$ & $\begin{array}{c}\text { Mori } 74^{+} \\
\text {transconjugants } \dagger\end{array}$ \\
\hline J62-I(R772) & PM5006 & $5 \times 10^{-6}$ & 0/10 \\
\hline $\mathrm{J} 62-\mathrm{I}\left(\mathrm{R} 77^{2}\right)$ & PM5006(MorI74R772) $\mathrm{K}^{\mathrm{s}}$ & $6 \times 10^{-6}$ & $10 / 10$ \\
\hline $\mathrm{J} 62-\mathrm{I}\left(\mathrm{R} 77^{2}\right)$ & PM5006(R772) $\mathrm{K}^{\mathrm{s}}$ & $5 \times 10^{-6}$ & $0 / 10$ \\
\hline J62-I (R772) & P29nal-r(Mori 74R 772) $\mathrm{K}^{\mathrm{s}}$ & $I \times 10^{-6}$ & $10 / 10$ \\
\hline J62-I)R772) & P29nal-r(R772)K & $\mathrm{I} \times 10^{-6}$ & $0 / 10$ \\
\hline $\mathrm{J} 62-\mathrm{I}\left(\mathrm{R} 77^{2}\right)$ & P29 & $1 \times 10^{-6}$ & $0 / 10$ \\
\hline $\mathrm{J} 62-\mathrm{I}(\mathrm{R} 447 b)$ & PM5006(Mor I 74R447b) $\mathrm{A}^{\mathrm{s}} \mathrm{K}^{\mathrm{s}}$ & $4 \times 10^{-6}$ & $10 / 10$ \\
\hline $\mathrm{J} 62-\mathrm{r}(\mathrm{R} 447 b)$ & PM5006 & $5 \times 10^{-6}$ & $0 / 10$ \\
\hline
\end{tabular}

\section{Transduction of $\mathrm{R} 772$ to Mor $174^{+}$and MorI $74^{-}$recipients}

Phage lysates 5006M.PM5006(R772) and PL25.P29(R772) transduced the kanamycin resistance marker of $R$ factor $R 772$ to strains PM5006(Mor174R772) $\mathrm{K}^{\mathrm{s}}$ and P29nal $r$ (Mor $174 \mathrm{R}_{772}$ ) $\mathrm{K}^{\mathrm{s}}$ at frequencies of $7 \times 10^{-7}$ and $5 \times 10^{-7}$ per p.f.u. adsorbed, respectively. When recipient organisms did not have MorI 74 as resident, these frequencies were about I000-fold lower. This was irrespective of whether or not MorI74 was resident in the organism on which the lysate had been made (Table 4, lines I to I I). Recipients PM5006 and P29 were transduced to kanamycin resistance at the same low frequencies as PM5006(R772) $\mathrm{K}^{\mathrm{s}}$ and P29nal-r(R772)Ks, respectively (Table 4, lines 2, 5 and 8, I I). When R772 was transduced into $\mathrm{J} 62$ by phage Pr, the presence of MorI 74 in the recipient was immaterial (Table 4, lines 12, I3). These results indicated that the resident Mor I 74 fulfilled a function in increasing the transduction efficiency of R772 by phages 5006M and PL25. This function appeared to be specific to MorI74 since the presence of other plasmids in the recipient, viz. P-lac, Ri92-7, R753 (Table 4, lines 14 to I6) and R755 and R905 (not shown), did not affect the 
Table 4. Effect of Mori74 on transduction frequency of plasmid markers

Phage at an m.o.i. of about 0.5 was added to $1 \mathrm{ml}$ of an exponentially growing culture of the recipient strain and incubated for $20 \mathrm{~min}$. The suspension was then filtered through a Millipore membrane, and the membrane with impinged cells was kept on nutrient agar for $2 \mathrm{~h}$ before transfer to selective medium. Where appropriate, transductants were replicated to morganocin 174 indicator plates. For recipient controls, phages 5006M.PM5006, PL25.P29 and PI.J62 were used.

$\begin{aligned} \begin{array}{r}\text { Expt } \\ \text { no. }\end{array} & \text { Phage lysate } \\ \text { I } & \text { 5006M.PM5006(R772) } \\ 2 & \text { 5006M.PM5006(R772) } \\ 3 & \text { 5006M.PM5006(Mor I4R772) } \\ 4 & \text { 5006M.PM5006(Mor I7R772) } \\ 5 & \text { 5006M.PM5006(R772) } \\ 6 & \text { 5006M.PM5006(R772) } \\ 7 & \text { PL25.P29nal-r(R772) } \\ 8 & \text { PL25.P29nal-r(R772) } \\ 9 & \text { PL25.P29nal-r(Mori 74R772) } \\ \text { I0 } & \text { PL25.P29nal-r(MorI74R772) } \\ 1 \text { I } & \text { PL25.P29nal-r(R772) } \\ \text { I2 } & \text { Pr.J62-I(R772) } \\ 13 & \text { P1.J62-I(R772) } \\ \text { I4 } & \text { 5006M.PM5006(R772) } \\ \text { I5 } & \text { 5006M.PM5006(R772) } \\ \text { I6 } & \text { 5006M.PM5006(R772) } \\ \text { I7 } & \text { 5006M.PM5006(RS-a) } \\ \text { I8 } & \text { 5006M.PM5006(RS-a) } \\ \text { 19 } & \text { 5006M.PM5006(R392) } \\ 20 & \text { 5006M.PM5006(R392) } \\ 2 \text { I } & \text { 5006M.PM5006(R397) } \\ 22 & \text { 5006M.PM5006(R397) } \\ & \end{aligned}$

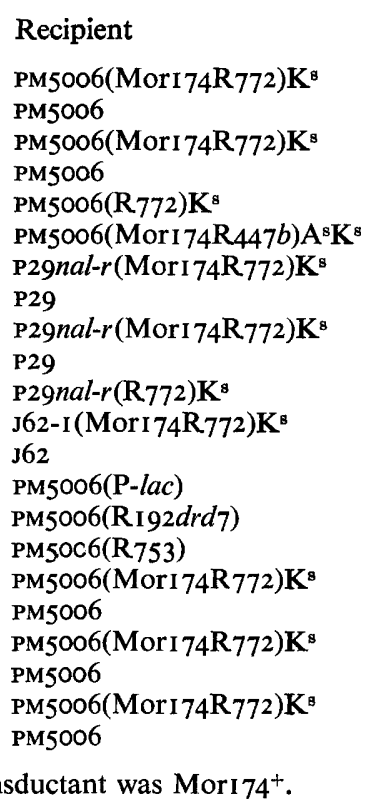

\begin{tabular}{|c|c|}
\hline $\begin{array}{l}\text { Selected } \\
\text { marker }\end{array}$ & $\begin{array}{c}\text { Transductio } \\
\text { frequency } \\
\text { per p.f.u. } \\
\text { adsorbed }\end{array}$ \\
\hline $\mathbf{K}$ & $7 \times 10^{-7}$ \\
\hline $\mathbf{K}$ & $8 \times 10^{-10}$ \\
\hline $\mathbf{K}$ & $8 \times 10^{-7}$ \\
\hline $\mathbf{K}$ & $\mathrm{I} \times \mathrm{IO}^{-9 *}$ \\
\hline $\mathbf{K}$ & $1 \times 10^{-9}$ \\
\hline $\mathrm{K}$ & $9 \times 10^{-7}$ \\
\hline $\mathbf{K}$ & $5 \times 10^{-7}$ \\
\hline $\mathbf{K}$ & $3 \times 10^{-10}$ \\
\hline $\mathbf{K}$ & $5 \times 10^{-8}$ \\
\hline $\mathbf{K}$ & $\mathrm{I} \times 1 \mathrm{I}^{-10}$ \\
\hline $\mathbf{K}$ & $\mathrm{I} \times 1 \mathrm{IO}^{-10}$ \\
\hline $\mathbf{K}$ & $\mathrm{I} \times 1 \mathrm{IO}^{-6}$ \\
\hline $\mathbf{K}$ & $\mathrm{I} \times \mathrm{IO}^{-6}$ \\
\hline $\mathbf{K}$ & $8 \times 10^{-10}$ \\
\hline $\mathbf{K}$ & $7 \times 10^{-10}$ \\
\hline $\mathbf{K}$ & $5 \times 10^{-10}$ \\
\hline $\mathbf{S}$ & $8 \times 10^{-7}$ \\
\hline $\mathbf{S}$ & $8 \times 10^{-7}$ \\
\hline $\mathbf{K}$ & $2 \times 10^{-9}$ \\
\hline $\mathbf{K}$ & $2 \times 10^{-9}$ \\
\hline $\mathbf{K}$ & $2 \times 10^{-9}$ \\
\hline $\mathbf{K}$ & $2 \times 10^{-9}$ \\
\hline
\end{tabular}

\footnotetext{
* One transductant was MorI $74^{+}$.
}

transduction frequency. The function of Mor 74 appeared to be specific for the transduction of $\mathrm{R}_{772}$ since plasmids $\mathrm{RS}-\mathrm{a}, \mathrm{R} 392$ and $\mathrm{R} 397$ were transduced with the same frequency to recipients with or without MorI 74 (Table 4 , lines $I 7$ to 22). It was not possible to investigate whether lysates 5006M.PM5006(MorI 74R772) and PL25.P29(MorI 74R772) could transduce the morganocin plasmid due to lack of selection, but kanamycin-resistant transductants (Table 4, lines 3, 4) were screened for concomitant acquisition of Mori 74. One of three transductants of PM5006 transduced with lysate 5006M.PM5006(MorI 74R772) was Mor I 74 ${ }^{+}$. Properties of this transductant are described below. Phages 5006M and PL25 showed the same dependence of transduced R772 on resident MorI 74 and further experiments were done only with PM5006 transductants.

\section{Properties of PM5006(Mori $74 \overline{\mathrm{R} 772})$ and $\mathrm{PM} 5006(\overline{\mathrm{R} 772})$}

Segregation pattern. Resident MorI74 was not displaced by transduced R772, neither did it play a role in maintenance of the transduced marker since markers of the two plasmids were lost independently (Table 5, line $\mathrm{I}$ ). The kanamycin resistance marker was lost at a higher frequency from PM5006 $(\overline{\mathrm{R} 772})$ than from PM5006(MorI74 $\overline{\mathrm{R} 772}$ ) (Table 5, lines I, 2).

Conjugal ability of $\overline{\mathbf{R} 772}$. R772 transduced to organisms containing MorI74 could be transferred by conjugation with the same frequency as the original $R 772$ (Table 6, lines $I, 2$ ) and could mobilize MorI 74. The MorI74- segregant, PM5006(MorI74 $\overline{\mathrm{R}_{772}}$ )MorI $74^{-}$, had 


\section{Table 5. Loss of transduced markers of MorI 74 and $\mathbf{R 7 7 2}$}

Overnight cultures grown in non-selective broth were plated on MacConkey agar to yield about 80 clones per plate. These were replicated to kanamycin agar or plates seeded with morganocin 174 indicator. Kanamycin-sensitive and morganocin-negative clones were subsequently replicated to morganocin indicator and kanamycin agar plates respectively.

\begin{tabular}{|c|c|c|c|c|}
\hline \multirow[b]{2}{*}{ Transductant } & \multicolumn{4}{|c|}{ Segregants $(\%)$} \\
\hline & Mori $74^{+} \mathbf{R}_{72^{-}}^{-}$ & Mori $74^{-R} \mathbf{R 7 2}^{+}$ & Mori 74-R772- & $\mathbf{R} 77^{-}$ \\
\hline PM5006(Mor I 74 $\overline{\mathrm{R} 772)}$ & 0.75 & $2 \cdot 0$ & 0.06 & \\
\hline PM5006 $\left(\overline{\mathrm{R}_{772}}\right)$ & & & & $2 \cdot 5$ \\
\hline PM5006( $\overline{\text { Mor I74R772) }}$ & $\mathrm{I} \cdot 5$ & 0.01 & 0.64 & \\
\hline
\end{tabular}

Table 6. Conjugal ability of transduced markers of $\mathrm{R} 772$

Mating experiments were done as in Table 2. Kanamycin resistance was the selected marker and donors were counterselected with nalidixic acid. Where appropriate, transconjugants were replicated to morganocin 174 indicator plates.

\begin{tabular}{|c|c|c|c|}
\hline Expt no. & Donor & Recipient & $\begin{array}{c}\text { Selected marker } \\
\text { transfer* }\end{array}$ \\
\hline I & PM5006(Mor174R772) & J62-I & $\mathrm{I} \times 10^{-6}(35) \dagger$ \\
\hline 2 & PM5006(Mor I 74 $\overline{\mathrm{R}_{772}}$ ) & $\mathrm{J} 62-\mathrm{I}$ & $1 \times 10^{-6}(33)$ \\
\hline 3 & PM5006(Mor I 74 $\overline{\mathrm{R} 772}$ )Mor I 74- & J62-I & $1 \times 10^{-6}$ \\
\hline 4 & PM5006( $\left.\overline{\mathrm{R}_{772}}\right)$ & J62-1 & $<\mathrm{I} \times 1 \mathrm{IO}^{-9}$ \\
\hline 5 & PM5006 $(\overline{\mathrm{R} 772})$ & J62-I(Mori 74R772)K $\mathrm{K}^{\mathrm{s}}$ & $<\mathrm{I} \times \mathrm{IO}^{-9}$ \\
\hline 6 & PM5006(Mor 174 $\overline{\mathrm{R} 772}$ ) & J62-I(Mor I4R772)K & $\mathrm{I} \times 10^{-6}$ \\
\hline 7 & PM5006( $\overline{\text { Mor174R772 }})$ & J62-I & $<\mathrm{I} \times \mathrm{IO}^{-9}$ \\
\hline 8 & PM5006(MorI74R772 & P29nal-r & $<\mathrm{I} \times \mathrm{IO}^{-9}$ \\
\hline
\end{tabular}

* Frequency per donor cell.

$\dagger$ Numbers in parentheses indicate the percentage cotransfer of morganocinogeny.

a similar transfer frequency (Table 6, line 3). In contrast, $\mathbf{R 7 7 2}$ transduced into PM5006 lacking a resident MorI74 factor could not transmit the kanamycin resistance marker (Table 6, line 4). The presence of MorI74 in the recipient did not influence the transfer frequency (Table 6, lines 5, 6).

Transduction by induced lysates. Lysates of phage $5006 \mathrm{M}$ induced from transductants PM5006(MorI74 $\overline{\mathrm{R} 772}$ ) again transduced kanamycin resistance to Mori $74^{+}$recipients at a frequency about I000-fold higher than to MorI74- recipients (Table 7, lines I, 2). Phage induced from rare transductants, PM5006 $\left(\overline{R_{772}}\right)$, transduced kanamycin resistance at high frequency (Table 7 , lines 3,4 ).

\section{Properties of PM5006( $\overline{(\text { MorI74R772) }}$}

Segregation pattern. The transductant which had received markers of MorI 74 and $\mathbf{R} 772$ simultaneously (Table 4, line 4) lost the markers independently (Table 5, line 3).

Conjugal ability. This transductant could not transfer kanamycin resistance or morganocinogeny to P29nal-r or J62-I (Table 6, lines 7,8 ).

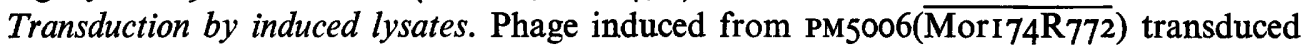
kanamycin resistance to PM5006 and PM5006(P-lac) at frequencies of $5 \times 10^{-8}$ per p.f.u. adsorbed. About $70 \%$ of transductants were MorI $74^{+}$(Table 7 , lines 5, 6). Transductants of PM5006, PM5006(MorI74R772), could not transfer markers by conjugation (Table 6, 
Table 7. Transduction of markers by u.v.-induced lysates of transductants

Transductions were done as in Table 5; kanamycin resistance was the selected marker.

\begin{tabular}{|c|c|c|c|c|c|}
\hline $\begin{array}{c}\text { Expt } \\
\text { no. }\end{array}$ & Phage lysate & M.o.i. & Recipient & $\begin{array}{l}\text { Transduction } \\
\text { frequency per } \\
\text { p.f.u. adsorbed }\end{array}$ & $\begin{array}{c}\text { Conjugal } \\
\text { transfer of } \\
\text { selected } \\
\text { marker* }\end{array}$ \\
\hline I & 5006M.PM5006(Mor174 $\overline{\mathrm{R} 772}$ ) & $0 \cdot 2$ & PM5006 & $1 \times 10^{-9}$ & 0/10 \\
\hline 2 & 5006M.PM5006(Mor I 74 $\overline{\mathrm{R} 772}$ ) & 0.2 & PM5006(Mori 74R 772) $\mathrm{K}^{\mathrm{s}}$ & $8 \times 10^{-7}$ & $0 / 20$ \\
\hline 3 & 5006M.PM5006 $\left(\overline{\mathrm{R}_{772}}\right)$ & 0.1 & PM5006 & $2 \times 10^{-1}$ & o/10 \\
\hline 4 & 5006M.PM5006 $\left(\overline{\mathrm{R}_{772}}\right)$ & $0 . \mathrm{I}$ & PM5006(Mor I 74R772)K & $4 \times 10^{-2}$ & o/10 \\
\hline 5 & 5006M.PM5006( $\overline{\text { MorI } 74 R 772}$ ) & 0.2 & PM5006 & $5 \times 10^{-8}(69) \dagger$ & $0 / 15$ \\
\hline 6 & 5006M.PM5006( $\overline{\text { MorI74R772 }}$ ) & $0 \cdot \mathrm{I}$ & PM5006(P-lac) & $5 \times 10^{-8}(7 \mathrm{I})$ & $4 / 4$ \\
\hline
\end{tabular}

Table 8. Production of morganocin by MorI $74^{+}$organisms

Exponentially growing organisms were induced with mitomycin C. At intervals samples were centrifuged and the supernatant fluids were assayed for morganocin I 74 activity by spotting dilutions on lawns seeded with morganocin indicator bacteria. The morganocin titres are expressed as the reciprocal of the highest dilution which gave a clear zone of inhibition.

\begin{tabular}{|c|}
\hline Organism \\
\hline PM5006(Mori 74R772) \\
\hline 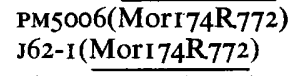 \\
\hline J62-I $(\overline{\text { Mor I 74R772 }})$ \\
\hline J62-I (P-lac $\overline{\text { Mor I 74R77 }}$ \\
\hline
\end{tabular}

Time after induction (h) $\ldots$
Morganocin titre

$\begin{array}{rrrrrrr}\circ & 2 & 4 & 8 & 24 & 48 & 72 \\ \circ & 0 & 0 & 4 & 16 & 16 & 32 \\ 0 & 0 & 0 & 4 & 8 & 16 & 32 \\ 0 & 8 & 16 & 2 & 0 & 0 & 0 \\ 0 & 4 & 16 & 4 & 0 & 0 & 0 \\ 6 & 8 & 16 & 4 & 6 & 6 & 6\end{array}$

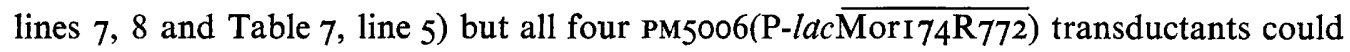
transfer markers to J62-I (Table 7, line 6) and transconjugants selected for kanamycin resistance were usually $l a c^{+}$and always MorI74+. These transconjugants, J62-I(Plac $\overline{\mathrm{Mor} I 74 \mathrm{R} 772}$ ), in turn transferred their markers to PM5006. All transconjugants from the latter cross selected for kanamycin resistance were MorI $74^{+}$but only about $50 \%$ had also acquired the lac marker (results not shown). Lysates of phage $5006 \mathrm{M}$ prepared lytically on

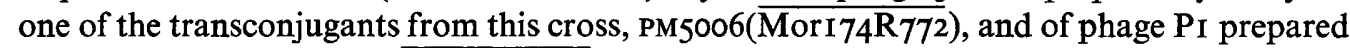
on the parent $\mathrm{J62}-\mathrm{I}(\mathrm{P}-\mathrm{lac} \overline{\mathrm{Mor}} \mathrm{I74}$ 772 $)$, showed $100 \%$ cotransduction of the kanamycin resistance marker and morganocinogeny in 200 transductants of each phage lysate.

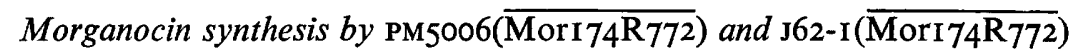

The morganocin titres produced by PM5006( $\overline{\text { MorI74R772 }}$ ) and J62-I $(\overline{\text { MorI74R772 }})$ did not exceed those of the corresponding organisms which had received Mor 144 by conjugation (Table 8).

\section{DISCUSSION}

Mori74 could only be introduced into the hosts of transducing phages through the mediation of R plasmid $\mathbf{R} 772$ or other plasmids tested (Table 2). To obtain these hosts with only the MorI 74 marker, spontaneous loss of the single r-determinant of $R_{772}$ had to be 
subsequently selected. We consider that the kanamycin-sensitive organisms so obtained had segregated the entire plasmid because they could no longer transfer the Mor 74 plasmid to other strains and surface exclusion, to entry of the homologous plasmid, was lacking (Table 3) (Meynell, 1969; see also Meynell, Meynell \& Datta, 1968). Should the plasmid R772 in the Mor $174^{+}$host merely have undergone some form of inactivation of the kanamycin resistance gene, recombination of incoming transduced $R_{772}$ with the remaining homologous fragment might possibly account for the increased transduction frequency to Mor $14^{+}$organisms compared with that to the corresponding Morr $74^{-}$hosts (Watanabe, Sakaizumi \& Furuse, 1968; Watanabe \& Ogata, 1970; and see Coetzee et al., 1973). A counter argument is that transduction of kanamycin resistance to Mor $174^{-}$hosts proceeded at the same low frequency as it did to kanamycin-sensitive derivatives of $R_{772}$ transconjugants of the same strains (Table 4 , lines 2, 5 and 8, II). These kanamycin-sensitive derivatives, which had never been in contact with Mor I74, had presumably arisen through segregation of the R772 plasmid. Finally, transduction of the kanamycin resistance marker of R772 also exhibited the same dependence on a resident MorI74 plasmid in a one-step ampicillin- and kanamycin-sensitive derivative of PM5006(MorI 74R447b) (Table 4, lines 2, 6). This derivative had probably segregated $\mathrm{R} 447 \mathrm{~b}$.

Transduced R772 in transductants PM5006(MorI74 $\overline{\mathrm{R} 772}$ ) was self-transmissible, could mobilize Mor 74 and was stable in Mor $174^{-}$segregants (Table 6, lines 2, 3). The transduced $\mathrm{R}$ plasmid markers thus possessed the properties by which the $\mathrm{R}$ factor is known and it may be concluded that the phage transduced all essential functions of the plasmid. The ability of Mor 74 to increase the transduction frequency (Table 4, lines I to I3) could be regarded as providing a function for establishment of the transduced markers of R772. Resident MorI 74 in the donor or recipient did not influence the transfer frequency of $\mathbf{R} 77_{2}$ markers by conjugation (Table 3; Table 6, lines 2,6).

Due to a small disparity in molecular weights between the DNA of R772 and that of phage $5006 \mathrm{M}$, accommodation of the former within the phage would be expected to involve transductional shortening (Shipley \& Olsen, 1975). In this particular case it could involve excision of a DNA sequence necessary for establishment after transduction. This function could possibly be provided by Mor 74 resident in the recipient.

Arber (I960) reported that the transfer by phage PI of plasmids which could readily be accommodated and which did not require integration in a resident genome of the recipient proceeded at the high frequencies of $\mathrm{I} \times \mathrm{IO}^{-5}$ to $5 \times 1 \mathrm{IO}^{-4}$ per p.f.u. adsorbed (but see Ozeki \& Stocker, 1958). The low frequencies of phage 5006M-mediated transduction of R772 to wildtype hosts could be a reflexion of the processes involved in transductional shortening. In this connexion it is interesting to note that phage PI transduction of R772 was not influenced by a resident Mor 144 in the recipient and proceeded at much higher frequencies than corresponding transductions by phages 5006M and PL25 which have smaller genomes (Table 4, lines I to I3).

Transduction of the kanamycin resistance marker of $\mathrm{R} 772$ with phage $5006 \mathrm{M}$ to PM5006 produced typical heterogenote-like transductants (Luria, Adams \& Ting, 1960; Coetzee, 1974b): they yielded high frequency kanamycin resistance transducing phage on u.v. induction (Table 7 , lines 3,4 ) and could not transfer the marker by conjugation (Table 6 , line 5). In contrast, transduction of $\mathrm{R}_{772}$ to $\mathrm{PM} 5006$ (Mor I $74 \mathrm{R}_{772}$ ) $\mathrm{K}^{\mathrm{s}}$ resulted in the paradoxical situation of having single transductant clones which could yield kanamycin resistance transducing phage on u.v. induction (Table 7, lines 1,2 ) and transfer the same marker by conjugation, using phage-resistant bacteria as recipients (Table 6, line 2). Phage 5006M did not transduce the kanamycin marker at high frequency as would have been expected if 
the phage components and marker had been induced from the chromosome as a single unit (Luria et al., 1960). An explanation could be that, in the original transduction, incoming transduced R772 DNA was severed from the phage component (Schmieger, 1970). The former then established itself as an independent plasmid while the latter integrated in tandem to the cryptic prophage of PM5006 (Krizsanovich, 1973; Coetzee, 1974b) and in this way rendered the latter inducible. MorI74 could function in connexion with the severance mentioned above and/or with establishment of dissociated DNA fragments.

Wild-type $\mathbf{R}$ factors, in addition to carrying the genes for various r-determinants, may also code for colicin I (see Meynell \& Cooke, I969), and a recombinant between a non selftransmissible plasmid coding for EcoR I, colicin Er and the ampicillin resistance gene of R factor RI has been described (Smith et al., 1976). Fredericq \& Delhalle (1972) obtained an array of recombinants between r-determinants of $\mathrm{R}$ factors $\mathrm{R} 45$ or $\mathrm{R} 50$ and ColV and ColB by using phage PI as a transducing vehicle. Also the kanamycin resistance marker of plasmid pSCro5 was recombined in vitro with ColEI (Hershfield et al., 1974) or a mini ColEr plasmid (Lovett \& Helinski, I976). The recombinant described here was selected by transductional techniques. Joint transduction of markers is an accepted method of demonstrating linkage between the loci concerned (Clowes, I972; and see Coetzee, I974a). Recombination had probably occurred during conjugal cotransfer of markers from the $P$. morganii host to PM5006 (Table 2, line 2). However, ability to recombine stably is not necessarily a requirement for conjugal cotransfer (see Kameda et al., I969; Cooper, I97 I). This is borne out by the fact that phage raised on the transconjugant clone also transduced kanamycin resistance independently (Table 4, line 4). The finding that the cotransductant lost the markers independently (Table 5, line 3 ) probably meant that, as above, the incoming recombinant transduced particle split into two or, in some cells, all three components. The phage portion was always detached and integrated in the host chromosome, as mentioned above, to render the system inducible (Table 7 ). The $\mathrm{R}$ plasmid portion had probably undergone transductional shortening (Shipley \& Olsen, 1975) to render it, and combined (or severed) Mori 74, non-transferrable by conjugation (Table 6, lines 7,8 ) but still capable of independent replication. Induction of these transductants would again yield some cotransducing phage particles. On transduction to a host possessing a resident conjugative plasmid like P-lac (Table 2, line 7) these cotransduced particles, after the usual severance of phage genes, would be transmissible by conjugation to other hosts. Phage prepared lytically on the latter would be expected to cotransduce the markers at low frequency.

\section{REFERENCES}

AdAms, M. H. (1956). Methods of study of bacterial viruses. Methods in Medical Research 2, I-73.

ARBER, W. (1960). Transduction of chromosomal genes and episomes in Escherichia coli. Virology Ir, 273288.

Clowes, R. C. (1972). Molecular structure of bacterial plasmids. Bacteriological Reviews 36, 361-405.

Clowes, R. C. \& Hayes, W. (1968). Experiments in Microbial Genetics, p. 227. Oxford and Edinburgh: Blackwell Scientific Publications.

Coetzee, J. N. (1974a). Properties of Proteus and Providence strains harbouring recombinant plasmids between P-lac and Ridrdi9 or R447b. Journal of General Microbiology 8o, I I9-130.

Coetzee, J. N. (I974b). High frequency transduction of kanamycin resistance in Proteus mirabilis. Journal of General Microbiology 84, 285-296.

Coetzee, J. N. (1975). Transduction of a Proteus vulgaris strain by a Proteus mirabilis bacteriophage. Journal of General Microbiology 89, 299-309.

Coetzee, J. N. \& Smit, J. A. (1970). Properties of Proteus mirabilis phage 1 3 vir. Journal of General Virology 9 , 247-249.

Coetzee, J. N., Smit, J. A. \& Prozesky, O. W. (I966). Properties of Providence and Proteus morganii transducing phages. Journal of General Microbiology 44, 167-176. 
Coetzee, J. N., Datta, N. \& Hedges, R. W. (1972). R Factors from Proteus rettgeri. Journal of General Microbiology 72, 543-552.

Coetzee, J. N., Datta, N., Hedges, R. W. \& Appelbaum, P. C. (1973). Transduction of R factors in Proteus mirabilis and $P$. rettgeri. Journal of General Microbiology 76, 355-368.

COOPER, P. (197I). Interaction of a colicinogenic factor with a resistance factor and with the fertility factor $F$ in Escherichia coli K-12. Genetical Research I7, 15 I-1 59.

FredericQ, P. \& Delhalle, E. (1972). Recombinaison entre facteurs R et facteurs colicinogènes chez Escherichia coli KI2. Annales de l'Institut Pasteur 122, 909-921.

Hedges, R. W. (1975). R factors from Proteus mirabilis and P. vulgaris. Journal of General Microbiology 87, 3OI-3II.

Hedges, R. W. \& DAtTA, N. (I97I). $f^{-}$R factors giving chloramphenicol resistance. Nature, London 234, 220-22I.

Hedges, R. W., Datta, N., Coetzee, J. N. \& Dennison, S. (1973). R factors from Proteus morganii. Journal of General Microbiology 77, 249-259.

Hedges, R. W., Jacob, A., Datta, N. \& Coetzee, J. N. (1975). Properties of plasmids produced by recombination between R factors of groups J and FII. Molecular and General Genetics 140, 289-302.

Hershfield, V., Boyer, H. W., Yanofsky, C., Lovett, M. A. \& Helinski, D. R. (1974). Plasmid ColEi as a molecular vehicle for cloning and amplification of DNA. Proceedings of the National Academy of Sciences of the United States of America 7r, 3455-3459.

IkedA, H. \& TomizaWA, J.-I. (r965). Transducing fragments in generalized transduction by phage PI. I. Molecular origin of the fragments. Journal of Molecular Biology 14, 85-109.

Ikeda, H. \& Tomizawa, J.-I. (I968). Prophage PI, an extrachromosomal replication unit. Cold Spring Harbor Symposia on Quantitative Biology 33, 79I-798.

Kameda, M., Harada, K., Suzuki, M. \& MitsuHashi, S. (1969). Formation of transferable drug resistance factor by recombination between resistance determinants and transfer factors. Japanese Journal of Microbiology 13, 255-262.

Krizsanovich, K. (I973). Cryptic lysogeny in Proteus mirabilis. Journal of General Virology 19, 31 I-320.

LOVETT, M. A. \& HelinSKi, D. R. (I976). Method for the isolation of the replication region of a bacterial replicon: construction of a mini-F' $\mathrm{km}$ plasmid. Journal of Bacteriology 127, 982-987.

LuRIA, S. E., ADAms, J. N. \& TING, R. C. (1960). Transduction of lactose-utilizing ability among strains of $E$. coli and $S$. dysenteriae and the properties of the transducing phage particles. Virology 12, 348-390.

Meynell, E. \& CoOKe, M. (I969). Repressor-minus and operator-constitutive de-repressed mutants of F-like R factors: their effect on chromosomal transfer by HfrC. Genetical Research 14, 309-313.

Meynell, E. \& Datta, N. (I966). The relation of resistance transfer factors to the F-factor (sex-factor) of Escherichia coli K12. Genetical Research 7, 134-I40.

Meynell, E. \& Datta, N. (1967). Mutant drug resistance factors of high transmissibility. Nature, London 2I4, 885-887.

Meynell, E., Meynell, G. G. \& Datta, N. (I968). Phylogenetic relationships of drug-resistance factors and other transmissible bacterial plasmids. Bacteriological Reviews 32, 55-83.

Meynell, G. G. (1969). Exclusion, superinfection immunity and abortive recombinants in $\mathrm{I}^{+} \times \mathrm{I}^{+}$bacterial crosses. Genetical Research 13 , I I3-II 5.

Ozeki, H. \& Stocker, B. A. D. (1958). Phage-mediated transduction of colicinogeny in Salmonella typhimurium. Heredity 12, 525-526.

Schmieger, H. (1970). The molecular structure of the transducing particles of Salmonella phage P22. II. Density gradient analysis of DNA. Molecular and General Genetics ro9, 323-337.

ShIPLEY, P. L. \& OLSEN, R. H. (1975). Isolation of a nontransmissible antibiotic resistance plasmid by transductional shortening of R factor RP1. Journal of Bacteriology 123, 20-27.

Smith, H. R., Humphreys, G. O., Willshaw, G. A. \& ANDerson, E. S. (1976). Characterisation of plasmids coding for the restriction endonuclease EcoR1. Molecular and General Genetics 143, 319-325.

Watanabe, T. \& OGata, Y. (1970). Abortive transduction of resistance factor by bacteriophage P22 in Salmonella typhimurium. Journal of Bacteriology 102, 596-597.

Watanabe, T., Sakaizumi, S. \& Furuse, C. (1968). Superinfection with $\mathrm{R}$ factors by transduction in Escherichia coli and Salmonella typhimurium. Journal of Bacteriology 96, 1796-1802.

Williams, J. A. (1977). Mobilization of morganocin 174 plasmid and kinetics of morganocin production in Proteus and Escherichia coli hosts. Antimicrobial Agents and Chemotherapy (in the Press).

YAmAmoto, K. R. \& AlbeRTS, B. M. (1970). Rapid bacteriophage sedimentation in the presence of polyethylene glycol and its application to large-scale virus purification. Virology 40, 734-744. 